\title{
Ten minutes with Dr Gregory R Ciottone, MD, FACEP, FFSEM, President of the World Association for Disaster and Emergency Medicine
}

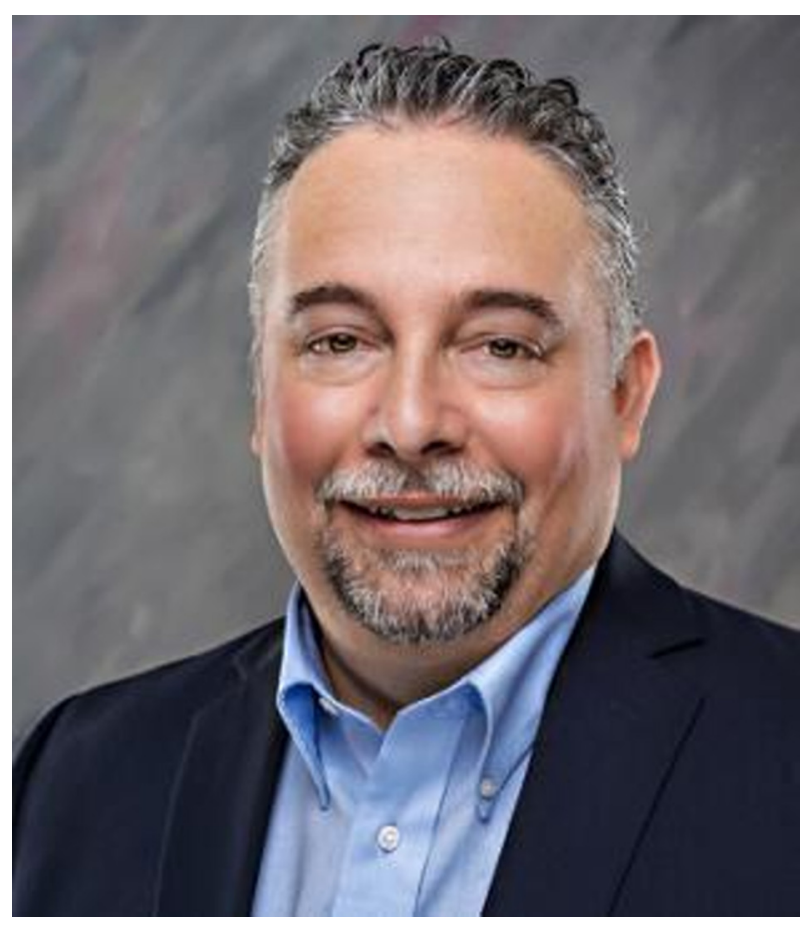

FIRST AND FOREMOST, ARE THERE ANY KEY LEADERSHIP MESSAGES YOU WANT TO GET OUT TO OUR READERSHIP?

The current COVID-19 pandemic is a global crisis that is unprecedented in recent history. As healthcare systems are being overwhelmed and economies are being decimated, we are doing a disservice to the world's population if we do not provide clear leadership and data-driven strategies. Each sovereign nation must do this, but we also must understand that we are a global community, and the actions we take as individual countries can have a dramatic effect on the world as a whole. When it comes to healthcare crisis leadership, there are no country borders.

\section{TELL US A LITTLE BIT ABOUT YOUR LEADERSHIP ROLE AND HOW IT IS CHANGING AS A RESULT OF THE PANDEMIC?}

I am the Director of the Beth Israel Deaconess Medical Center Fellowship in Disaster Medicine, the largest training programme in Disaster Medicine in the USA, which hosts 10 fellows each year from around the world. Utilising our fellows and more than 60 alumni, most of whom are in leadership positions in their home countries, we have pivoted with this disaster and became operational, creating a set of taskforces addressing specific issues around the COVID-19 disasters that have resulted in the implementation of our recommendations on local levels across the USA and around the world. It has been gratifying to see how our educational initiative has transitioned to becoming operational in response to COVID-19.

I am also the President of the World Association for Disaster and Emergency Medicine (WADEM), and as such am working with our leadership to create relevant content for our members, who span over 55 countries around the world, as well as the general public. We are focusing on information in the form of

\section{Biography}

Dr Gregory R Ciottone is the President of the World Association for Disaster and Emergency Medicine. He is an Associate Professor at Harvard Medical School, and an Instructor in the Department of Health Policy and Management at the Harvard T.H. Chan School of Public Health (HSPHS). He is the founder and director of the Beth Israel Deaconess Medical Center Fellowship in Disaster Medicine, the first of its kind at a Harvard teaching hospital, and the Medical Director for the National Preparedness Leadership Initiative, a joint programme of the HSPHS and the Harvard Kennedy School of Government. He also serves as a consultant to the White House Medical Unit.

Dr Ciottone has taught educational programmes in Disaster Medicine and Emergency Management in over 30 countries around the world, and has consulted domestically for the US State Department, Department of Health and Human Services, Department of Homeland Security, Department of Justice and the White House Medical Unit. He has written over 100 scholarly works, including the first and second editions of the leading textbook in the field, Ciottone's Disaster Medicine, and in 2016 was recognised by the Physician to the President for 'Outstanding Achievement In Support Of The White House Medical Unit And The President Of The United States'. Dr Ciottone was the 2018 recipient of the Disaster Medical Sciences Award from the American College of Emergency Physicians.

Dr Ciottone's clinical and field experience includes 25 years as a practicing emergency physician and over 500 missions as a flight physician on an aeromedical helicopter service. Early in his career, he worked with the United States Agency for International Development to create and implement sustainable disaster medical education programmes throughout the former Soviet Union that have trained over 50000 healthcare providers, and later helped lead an International Atomic Energy Agency nuclear accident preparedness programme for Eastern Europe. He also served as commander of one of the first federal disaster medical assistance teams (Massachuestts-2) into Ground Zero during the World Trade Center disaster on 11 September 2001, and has deployed to a number of other crises around the world, including the Haiti earthquake. Dr Ciottone has held visiting professorship posts in Disaster Medicine at Vrije Universiteit Brussel in Belgium and Universita del Piemonte Orientale in Italy.

webinars, podcasts and links to pertinent literature to provide a data-driven analysis of this pandemic. I believe it is important to have reliable sources of information, such as WADEM, WHO and CDC so that healthcare workers and global citizens can make educated decisions for themselves and their families.

\section{WHAT EVENTS IN YOUR PAST EXPERIENCE ARE MOST INFORMING YOUR LEADERSHIP IN THIS PANDEMIC?}

Perhaps the most significant past leadership experience I had in my career was the time I spent in the United States National Disaster Medical System as Commander of a level-1 Disaster 
Medical Assistance Team (Massachusetts 2), and leading that team as one of the first federal teams into Ground Zero on 11 September 2001. We remained onsite for 2 weeks and treated over 400 patients per day in our five medical treatment stations. I learnt a great deal about crisis leadership during that time, skills I continue to use today. Later, as Medical Director of Emergency Management at Beth Israel Deaconess Medical Center, I was able to help create important disaster preparedness and response plans for a major medical centre and Harvard teaching hospital, including a comprehensive plan for pandemic influenza.

Speaking globally about this pandemic, while I think there are important lessons SARS and other recent outbreaks have taught us about how to respond to novel viruses as they emerge, I believe there were crucial lessons from the Ebola outbreak that had we heeded may have impacted the current COVID-19 pandemic dramatically. Early containment is the most effective modality in the prevention of pandemics. ${ }^{1}$ Of note, and to be examined further when this crisis is over, we had a wake-up call about early containment 6 years ago. In 2014, I advocated for home self-quarantine of healthcare workers returning to the USA from treating Ebola patients in West Africa (who would fall under the category of 'sick contacts'), before the disease could take a foothold in the country. ${ }^{23}$ However, there was widespread pushback to that, with some saying that we should not be treating these returning doctors and nurses like 'pariahs'. Ebola, while a bit less infectious (R0 of $1.5-2.5$ vs of $2-3$ for SARS-CoV-2) is still quite contagious, and more importantly, nearly $100 \%$ of those infected required above ICU level care. We escaped an Ebola pandemic by containing it in West Africa, where the impact was unfortunately devastating, but can you imagine how it would have decimated our healthcare systems had we not? As a global community, we must heed the lessons from this second wake-up call, and irrespective of borders, understand now and in the future that we are all at risk if we do not work together.

\section{WHAT ARE YOU FINDING AS THE BIGGEST CHALLENGES?}

My biggest challenge is to try to guide my fellows and alumni through this unprecedented crisis that has no clear endpoint, and to deploy our system of taskforces to try to help navigate the varying responses in each of their countries. One of the biggest challenges in this crisis is that it is truly global. Either countries are currently in the hot zone and fully engaged in response activities, or they are in the preparedness phase, taking necessary steps to mitigate and respond to the pending surge. In a global pandemic, there are not the typical resources available to extend to neighbouring regions. In such a case, building local response capabilities can greatly enhance community resiliency. I believe that one lesson we will learn from the COVID-19 pandemic is that acute and postacute phase intrinsic healthcare response capabilities should be greatly enhanced on a regional level, and sustainable interagency healthcare emergency management systems should be enacted that transcend country borders.

\section{ANY PARTICULAR SURPRISES?}

I am somewhat surprised that after experience with the 1918 influenza, H1N1, H5N1, SARS, Ebola and other infectious disease outbreaks, we were still not able to contain this before it became a pandemic. I understand it is a novel virus, but so were the others when they first emerged. Going forward, we must understand the tremendous mitigative power of early containment, as well as early implementation of social distancing strategies. I fear we would not have many more chances to get this right. Imagine a virus emerges with the transmissibility of
SARS-CoV-2 (or worse say Mumps or Measles), and the case fatality rate of Rabies or Ebola. Our healthcare systems would be decimated and without aggressive containment and NonPharmaceutical Interventions, our very survival as a species would be threatened.

\section{ARE YOU SEEING ANY BEHAVIOURS FROM COLLEAGUES THAT ENCOURAGE OR INSPIRE YOU?}

Yes, I do. Some of the world's scientists, like Drs Anthony Fauci and Deborah Birx are doing a phenomenal job assimilating, analysing and conveying data. With their science analyses data-driven and modelling systems being accurate they are also conveying information to the public in an understandable and believable way. It is important to do good science during a prolonged crisis like a pandemic, but it is equally important to relay that information to the public in an understandable way, so citizens can take the steps required for community mitigation.

\section{HOW ARE YOU MAINTAINING KINDNESS AND COMPASSION?}

It is often hard when you are a professional and a Disaster Medicine expert to be that while also experiencing the disaster yourself. One can sometimes withdraw into personal difficulties, which can skew how you do your job and cause you to not be aware of how the crisis is affecting others. I am trying very hard to make an effort every day to understand and empathise with the plight of the many who have been personally affected by this crisis through loss of a loved-one or loss of a job, or simply loss of the normal. It is important in these very trying times to extend kindness and compassion in all directions. It should be extended to those you are leading, those you report to, and more importantly your family and others, who may not fully understand the medical and public health information as well as you do. Lack of reliable information and the unknowns involved with this crisis can lead to changes in behaviour, particularly when in home isolation. Understanding that and respecting others is important.

\section{ARE THERE ANY READINGS THAT YOU FIND HELPFUL FOR INSPIRATION AND SUPPORT THAT YOU WOULD RECOMMEND TO OTHERS?}

I recommend a great crisis leadership book called 'You're It: Crisis, Change, And How To Lead When It Matters Most'. ${ }^{4}$ I would also suggest taking some time to escape the onslaught of COVID news and information, which can be all-encompassing, and picking up a good book. Your mental health will benefit from some light reading in topics you enjoy. You will feel a lot better if you take the steps to maintain your own physical and mental health.

\section{WHAT ARE YOU LOOKING FOR FROM YOUR LEADERS?}

I expect my leaders to understand and practice principles of crisis leadership. Crisis leaders often have to make quick decisions with little and unreliable information. The ability to pivot as the crisis changes direction, as they all do, instead of panicking is perhaps the greatest characteristic of a crisis leader. When I teach my students, I often say 'better the planning than the plan'. I expect leaders to not be overly committed to a plan, rather that they have gone through enough preparedness and drills with their teams that the planning process is comfortable and efficient. This will allow them to better navigate a crisis. As the saying goes, if you have been to one disaster you have been to one disaster. No two crises are alike, and the ability to change 
direction when and however many times is required will set a crisis leader apart from others.

\section{WOULD YOU BE WILLING TO HAVE A FOLLOW-UP CHAT IN A FEW WEEKS TIME?}

I would be happy to.

\section{Gregory R Ciottone, ${ }^{1,2}$ Attila Hertelendy ${ }^{3}$}

${ }^{1}$ Emergency Medicine, Beth Israel Deaconess Medical Center, Boston, Massachusetts, USA

${ }^{2}$ Department of Emergency Medicine, Harvard Medical School, Boston, Massachusetts, USA

${ }^{3}$ College of Business, Department of Information Systems and Business Analytics, Florida International University, Miami, Florida, USA

\section{Correspondence to}

Attila Hertelendy, College of Business, Department of Information Systems and Business Analytics, Florida International University, Miami, FL 33199, USA; ahertele@fiu.edu

Correction notice This article has been corrected since it was published Online First. The date has been correctly changed from "9 November 2001 " to "11 September 2001" throughout the article.

Twitter Attila Hertelendy @drhertelendy

Funding The authors have not declared a specific grant for this research from any funding agency in the public, commercial or not-for-profit sectors.

Competing interests None declared.

Patient consent for publication Not required.

Provenance and peer review Not commissioned; internally peer reviewed.

Data availability statement Data sharing not applicable as no data sets generated and/or analysed for this study.

\section{(2) \\ OPEN ACCESS}

Open access This article is made freely available for use in accordance with BMJ's website terms and conditions for the duration of the covid-19 pandemic or until otherwise determined by BMJ. You may use, download and print the article for any lawful, non-commercial purpose (including text and data mining) provided that all copyright notices and trade marks are retained.

(C) Author(s) (or their employer(s)) 2020. Re-use permitted under CC BY-NC. No commercial re-use. See rights and permissions. Published by BMJ.

\section{D) Check for updates}

To cite: Ciottone GR, Hertelendy A. BMJ Leader 2020;4:154-156.

Received 20 April 2020

Revised 22 April 2020

Accepted 23 April 2020

Published Online First 13 May 2020

BMJ Leader 2020;4:154-156.

doi:10.1136/leader-2020-000269

\section{REFERENCES}

1 Wilder-Smith A, Freedman DO. Isolation, quarantine, social distancing and community containment: pivotal role for old-style public health measures in the novel coronavirus (2019-nCoV) outbreak. J Travel Med 2020;27. doi:10.1093/jtm/taaa020

2 YouTube. Dr. Ciottone on quarantine, 2014. Available: https://www.youtube.com/ watch?v=VpQ06k32_gU\&t=4s [Accessed 22 Apr 2020].

3 YouTube. Dr. Ciottone on quarantine 2, 2014. Available: https://www.youtube.com/ watch?v=gu1 KachF7jg\&t=11s [Accessed 22 Apr 2020].

4 Marcus LJ, McNulty EJ, Henderson JM, et al. You're it: crisis, change, and how to lead when it matters most. (public affairs, New York ISBN 978-1541768031), 2019. 